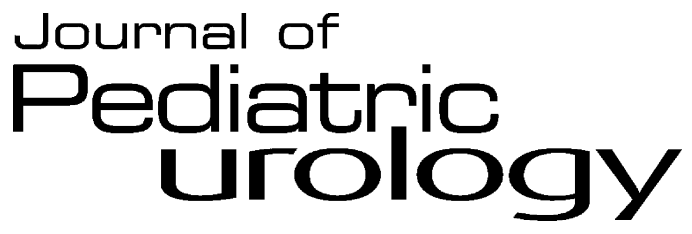

\title{
A 20-year study of persistence of lower urinary tract symptoms and urinary incontinence in young women treated in childhood
}

\author{
F. Petrangeli ${ }^{a}$, M.L. Capitanucci ${ }^{\text {b,* }}$, A. Marciano ${ }^{\text {b }}$, \\ G. Mosiello ${ }^{\text {b }}$, R. Alvaro ${ }^{a}, A$. Zaccara ${ }^{\text {b }}$, E. Finazzi-Agro ${ }^{\text {, }}$, \\ M. De Gennaro ${ }^{\text {b }}$
}

a School of Nursing, Tor Vergata University, Rome, Italy

b Urology, Robotic Surgery and Urodynamic Unit, Department of Pediatric Urology, Children's Hospital Bambino Gesú, Rome, Italy

' Department of Urology, Tor Vergata University, Rome, Italy

Received 1 August 2013; accepted 6 January 2014

Available online 5 February 2014

\section{KEYWORDS \\ Urinary incontinence; Lower urinary tract symptoms; \\ Lower urinary tract dysfunction}

\begin{abstract}
Objective: To determine whether urinary incontinence (UI) and lower urinary tract symptoms (LUTS) persist over years, patients treated for UI and LUTS in childhood were reevaluated in adulthood.

Materials and methods: Forty-seven women (cases) treated in childhood for daytime UI/LUTS (group A) and nocturnal enuresis (group B) self-completed (average age: $24.89 \pm 3.5$ years) the International Consultation on Incontinence Questionnaire for Female with LUTS (ICIQ-FLUTS). ICIQ-FLUTS was self-administered to 111 healthy women (average age: $23 \pm 5.1$ years) from a nursing school as a control group. Data obtained from ICIQ-FLUTS and quality of life (QoL) score $(0-10)$ were compared (Fisher's exact test) between patients and controls, and between group A $(n=28)$ and group B $(n=19)$.

Results: Prevalence of LUTS was higher in patients than in controls. The difference between patients and controls was statistically significant $(p=0.0001)$ for UI $(34 \%$ vs. $7 \%)$ and feeling of incomplete bladder emptying ( $49 \%$ vs. $28 \%$ ). QoL score was $>5$ in $59 \%$ of patients and $1 \%$ of controls $(p=0.0001)$. No significant differences were found between groups A and B.

Conclusions: UI and LUTS are confirmed in young women who suffered for the same condition in childhood. Longitudinal studies are needed to assess if these symptoms persist or are newly onset. (c) 2014 Journal of Pediatric Urology Company. Published by Elsevier Ltd. All rights reserved.
\end{abstract}

* Corresponding author. Tel.: +39 (0) 668592518.

E-mail address: mluisa.capitanucci@opbg.net (M.L. Capitanucci). 


\section{Introduction}

Urinary incontinence (UI) is a debilitating condition with a large negative impact on quality of life $(\mathrm{QoL})$ [1]. It is a more common problem in women than in men. For a variety of reasons, such as difference in study populations, definitions and measurement, estimates of UI prevalence differ widely. However, a review of 36 general population studies included in the 4 th International Consultation on Incontinence found a relevant prevalence of $\mathrm{UI}$ in the range of $25-45 \%$ for women [2]. Even in childhood, $\mathrm{UI}$ is a common condition. Approximately $5-10 \%$ of 7 -year-old children suffer from daytime $\mathrm{UI}$ and/or nocturnal enuresis (NE): NE is more common among boys than girls, while for daytime UI the reverse is true [3]. Several case-control studies [4-18] in women with UI hypothesized a possible link between lower urinary tract disorders in adulthood and $\mathrm{UI}$ and lower urinary tract symptoms (LUTS) already present in childhood. However, the significance of childhood UI and LUTS as risk factors for eventual adult lower urinary tract disorders and how many treatments of childhood LUTS will alter the prevalence of UI in adulthood remain to be clarified. The long-term evaluation of children with UI and LUTS up to adulthood would be helpful in confirming the link between lower urinary tract disorders in childhood and adulthood, and in clarifying the pathophysiological significance of childhood LUTS as predictors of UI and LUTS in women. To our knowledge, no study has investigated adult patients who suffered from UI and LUTS in childhood. In order to determine whether LUTS persist from childhood into adulthood, we reevaluated women who were treated for daytime UI and LUTS and NE in childhood.

\section{Material and methods}

From 1990 to 2001, 287 girls (average age: $10.3 \pm 3.2$ years) were treated for UI and LUTS. Name, date of birth, and address and telephone number of patients followed-up for at least 6 months were entered in a database, grouping patients in two main categories: (1) patients with daytime UI and LUTS (group A); (2) patients with NE (group B). No data on treatment and its result were reported in the database. However, in those years, motivational therapy, behavioral modification, and bladder training were performed in our center to treat children with both day- and night-time LUTS; oxybutinin and intranasal desmopressin were administered in children with overactive bladder and $\mathrm{NE}$, respectively.

In 2012, 151/287 patients who could be traced from the database were asked over the telephone to re-evaluate their urinary continence status and lower urinary tract function in adulthood, compiling the long form of the International Consultation on Incontinence $(\mathrm{ICl})$ Questionnaire for Females with LUTS (ICIQ-FLUTS) [19]. Of the 151 patients traced by telephone, 99 agreed to participate and received the ICIQ-FLUTS form via e-mail. The control group consisted of healthy young women attending nursing school who agreed to answer the same questionnaire.

The long form of the ICIQ-FLUTS is a self-administered questionnaire developed into a set of theme-driven modules that investigate the major aspects of LUTS and their impact on QoL. It consists of 36 items on UI, LUTS, and related QoL with a score of $0-10$. The reference period for symptom assessment is the 4 weeks preceding the day that the questionnaire is administered [19]. Items that investigate presence and related QoL score of $\mathrm{UI}(2 \mathrm{a}, 2 \mathrm{~b})$, voiding frequency $(26 a, 26 b)$, nicturia $(27 a, 27 b)$, urgency $(28 a$, 28b), bladder pain (29a, 29b), hesitancy (30a, 30b), straining to void $(31 \mathrm{a}, 31 \mathrm{~b})$, intermittency $(32 \mathrm{a}, 32 \mathrm{~b})$, burning feeling when urinating $(34 a, 34 b)$, and feeling of incomplete bladder emptying $(35 \mathrm{a}, 35 \mathrm{~b})$ were considered. Frequency of UI episodes was defined as every week (one or more times) and every day (one or more times). Nicturia was considered to occur once per night or more than once per night. Abnormal voiding frequency was considered as micturition that occurs every hour, every $2 \mathrm{~h}$, and every $4 \mathrm{~h}$ or longer. Severity of the remaining LUTS was graded based on frequency of occurrence (occasionally/sometimes and most/all of the time). QoL score $>5$ was considered as to have a relevant impact on QoL.

Prevalence of UI and LUTS and related QoL score were compared (Fisher's exact test) between patients and controls, and between group $A$ and group $B$.

\section{Results}

ICIQ-FLUTS was returned to $47 / 99$ patients who agreed to participate in the study (cases) and to 111 healthy women from the nursing school (controls). At the time of questionnaire compilation, the average age was $24.89 \pm 3.5$ (range 21-34) years in patients and $23 \pm 5.1$ (range 18-40) years in controls. The questionnaire was fully completed by cases. In the control group some items were missed (Tables 1 and 2): the average number of missing items was 11.7 (range 7-37).

Twenty-eight of 47 women were observed in childhood for daytime UI/LUTS (group A) at an average age of $9.6 \pm 4.1$ years (range $5-20$ years, median 11 years); the remaining 19 women presented with NE (group B) at an average age of $10.5 \pm 2.34$ years (range $5-15$ years; median 10 years).

Prevalence, frequency, and degree of severity of UI and LUTS, QoL score, and results of statistical comparison between patients and controls are shown in Table 1. Significant differences $(p<0.05)$ between patients and controls were found for UI (34\% vs. $7 \%$ ) and feeling of incomplete emptying (49\% vs. 28\%). QoL score related to UI and LUTS was $>5$ in $28 / 47$ (59\%) patients and in $2 / 111$ (1\%) controls $(p=0.0001)$.

Prevalence of UI and LUTS in adulthood, and results of statistical comparison between patients of group A and $B$ are shown in Table 2. UI and LUTS in adulthood did not significantly differ between group A and group B.

\section{Discussion}

In 1992, Burton et al. [5] reported that mothers with overactive bladder used different toilet training models than the general population; they postulated that the link between childhood enuresis and adult incontinence could be explained by a failure to learn how to achieve bladder 
Table 1 Prevalence of lower urinary tract symptoms (LUTS) in young women with a history of daytime urinary incontinence (UI) and LUTS and nocturnal enuresis in childhood (patients) and in a control population.

\begin{tabular}{|c|c|c|c|}
\hline LUTS in adulthood & $\begin{array}{l}\text { Patients } \\
n^{\circ} .(\%)\end{array}$ & $\begin{array}{l}\text { Controls } \\
n^{\circ} .(\%)\end{array}$ & $p$ \\
\hline UI & $16 / 47$ (34) & $8 / 111(7)$ & 0.0001 \\
\hline $\begin{array}{l}\text { - Every week } \\
\text { (once or more) }\end{array}$ & $12 / 16$ & $6 / 8$ & 1 \\
\hline $\begin{array}{l}\text { - Every day } \\
\text { (once or more) }\end{array}$ & $4 / 16$ & $2 / 8$ & \\
\hline $\begin{array}{l}\text { Impact on QoL: } \\
\text { average } \\
\text { score (range) }\end{array}$ & $1.27(0-10)$ & $0.5(0-6)$ & \\
\hline $\begin{array}{l}\text { Abnormal voiding } \\
\text { frequency }\end{array}$ & $32 / 47(68)$ & $78 / 105$ (74) & 0.4 \\
\hline - Every $1-2 \mathrm{~h}$ & $18 / 32$ & $44 / 78$ & 1 \\
\hline - Every $4 \mathrm{~h}$ or longer & $14 / 32$ & $34 / 78$ & \\
\hline $\begin{array}{l}\text { Impact on QoL: average } \\
\text { score (range) }\end{array}$ & $1.29(0-7)$ & $0.3(0-5)$ & \\
\hline Nicturia & $20 / 47(42)$ & $32 / 108$ (29) & 0.1 \\
\hline $\begin{array}{l}\text { - One episode } \\
\text { per night }\end{array}$ & $19 / 20$ & $30 / 32$ & 1 \\
\hline $\begin{array}{l}->1 \text { episode } \\
\text { per night }\end{array}$ & $1 / 20$ & $2 / 32$ & \\
\hline $\begin{array}{l}\text { Impact on QoL: } \\
\text { average } \\
\text { score (range) }\end{array}$ & $1(0-10)$ & $0.08(0-2)$ & \\
\hline Urgency & $22 / 47$ (47) & $38 / 107$ (35) & 0.2 \\
\hline $\begin{array}{l}\text { - Occasionally and } \\
\text { sometimes }\end{array}$ & $22 / 22$ & $38 / 38$ & 1 \\
\hline $\begin{array}{l}\text { - Most and all of } \\
\text { the time }\end{array}$ & - & - & \\
\hline $\begin{array}{l}\text { Impact on QoL: } \\
\text { average } \\
\text { score (range) }\end{array}$ & $0.92(0-8)$ & $0.2(0-3)$ & \\
\hline Bladde $r$ pain & $15 / 47(32)$ & $23 / 107(21)$ & 0.2 \\
\hline $\begin{array}{l}\text { - Occasionally and } \\
\text { sometimes }\end{array}$ & $15 / 15$ & $23 / 23$ & 1 \\
\hline $\begin{array}{l}\text { - Most and all of } \\
\text { the time }\end{array}$ & - & - & \\
\hline $\begin{array}{l}\text { Impact on QoL: } \\
\text { average } \\
\text { score (range) }\end{array}$ & $0.4(0-5)$ & $0.2(0-3)$ & \\
\hline Hesitancy & $19 / 45(40)$ & $46 / 107$ (43) & 1 \\
\hline $\begin{array}{l}\text { - Occasionally and } \\
\text { sometimes }\end{array}$ & $19 / 19$ & $44 / 46$ & 1 \\
\hline $\begin{array}{l}\text { - Most and all of } \\
\text { the time }\end{array}$ & - & $2 / 46$ & \\
\hline $\begin{array}{l}\text { Impact on QoL: } \\
\text { average } \\
\text { score (range) }\end{array}$ & $0.7(0-9)$ & $0.2(0-5)$ & \\
\hline Straining to void & $14 / 47$ (29) & $23 / 106$ (21) & 0.4 \\
\hline $\begin{array}{l}\text { - Occasionally and } \\
\text { sometimes }\end{array}$ & $13 / 14$ & $23 / 23$ & 0.3 \\
\hline $\begin{array}{l}\text { - Most and all of } \\
\text { the time }\end{array}$ & $1 / 14$ & - & \\
\hline $\begin{array}{l}\text { Impact on QoL: } \\
\text { average } \\
\text { score (range) }\end{array}$ & $0.6(0-10)$ & $0.08(0-2)$ & \\
\hline
\end{tabular}

Table 1 (continued)

\begin{tabular}{|c|c|c|c|}
\hline LUTS in adulthood & $\begin{array}{l}\text { Patients } \\
n^{\circ} .(\%)\end{array}$ & $\begin{array}{l}\text { Controls } \\
n^{\circ} .(\%)\end{array}$ & $p$ \\
\hline Intermittency & $22 / 47$ (47) & $47 / 106$ (44) & 0.8 \\
\hline $\begin{array}{l}\text { - Occasionally and } \\
\text { sometimes }\end{array}$ & $22 / 22$ & $47 / 47$ & 1 \\
\hline $\begin{array}{l}\text { - Most and all of } \\
\text { the time }\end{array}$ & - & - & \\
\hline $\begin{array}{l}\text { Impact on QoL: average } \\
\text { score (range) }\end{array}$ & $0.8(0-8)$ & $0.1(0-2)$ & \\
\hline $\begin{array}{l}\text { Feeling of incomplete } \\
\quad \text { emptying }\end{array}$ & $23 / 47$ (49) & $30 / 107$ (28) & 0.01 \\
\hline $\begin{array}{l}\text { - Occasionally and } \\
\text { sometimes }\end{array}$ & $20 / 23$ & $28 / 30$ & 0.6 \\
\hline $\begin{array}{l}\text { - Most and all of } \\
\text { the time }\end{array}$ & $3 / 23$ & $2 / 30$ & \\
\hline $\begin{array}{l}\text { Impact on QoL: } \\
\text { average } \\
\text { score (range) }\end{array}$ & $1.10(0-9)$ & $0.2(0-5)$ & \\
\hline $\begin{array}{l}\text { Burning feeling } \\
\quad \text { when urinating }\end{array}$ & $12 / 47(25)$ & $26 / 107$ (24) & 1 \\
\hline $\begin{array}{l}\text { - Occasionally and } \\
\text { sometimes }\end{array}$ & $12 / 12$ & $26 / 26$ & 1 \\
\hline $\begin{array}{l}\text { - Most and all of } \\
\text { the time }\end{array}$ & - & - & \\
\hline $\begin{array}{l}\text { Impact on QoL: } \\
\text { average } \\
\text { score (range) }\end{array}$ & $0.5(0-7)$ & $0.3(0-5)$ & \\
\hline
\end{tabular}

Note. $n^{\circ} .=$ number of subjects; QoL $=$ quality of life.

control at the time of potty training. Even if educational models in acquiring bladder control may be of great importance in predisposing the development of $\mathrm{UI}$ and LUTS, others pathophysiological mechanisms may offer an explanation for the potential link between UI and LUTS in children and adults. Different authors have described an increased risk of UI and LUTS in family members of women with $\mathrm{UI}$ and twin sisters, suggesting a possible genetic basis for lower urinary tract disorders [6-10]. In 2001, a locus on chromosome 17q for urge incontinence was identified [11]. Recently, microarray studies demonstrated the presence of regulatory elements and genes encoding structural proteins in patients with overactive bladder [12]. In adult women with bladder and bowel disorders, the presence of LUTS in childhood and its potential pathophysiological relationship with UI and LUTS in adulthood have been investigated by several case-control studies. Bower et al. [13] investigated 191 women referred to a urogynecological clinic compared with 251 controls. The authors reported a significant association between overactive bladder symptoms in adulthood and childhood. In evaluating the prevalence of bladder and bowel dysfunction in 56 adolescents and adults with NE, Bower et al., [14] demonstrated that bladder and bowel problems during childhood were significantly correlated with adolescent and adult NE. In particular, significant associations were found between childhood symptoms and adult overactive bladder, and between childhood emptying dysfunction and adult voiding dysfunction [14]. The 
Table 2 Comparison of the prevalence of lower urinary tract symptoms (LUTS) in adulthood between girls with daytime urinary incontinence (UI) and LUTS (group A) and girls with nocturnal enuresis (NE) (group B).

\begin{tabular}{llll}
\hline $\begin{array}{l}\text { LUTS in } \\
\text { adulthood }\end{array}$ & $\begin{array}{l}\text { 28 girls With } \\
\text { daytime } \\
\text { LUTS pts. (\%) }\end{array}$ & $\begin{array}{l}19 \text { girls With } \\
\text { NE pts. (\%) }\end{array}$ & $\begin{array}{l}p \text { (Fisher's } \\
\text { exact test) }\end{array}$ \\
\hline UI & $9 / 28(32)$ & $7 / 19(37)$ & 0.7 \\
$\begin{array}{l}\text { Abnormal } \\
\quad \text { voiding }\end{array}$ & $21 / 28(75)$ & $11 / 19(58)$ & 0.3 \\
$\quad$ frequency & & & \\
Nicturia & $13 / 28(46)$ & $7 / 19(37)$ & 0.5 \\
Urgency & $14 / 28(50)$ & $8 / 19(42)$ & 0.7 \\
$\begin{array}{l}\text { Bladder pain } \\
\text { Hesitancy }\end{array}$ & $10 / 28(36)$ & $5 / 19(26)$ & 0.5 \\
$\begin{array}{l}\text { Straining to void } \\
\text { Intermittency }\end{array}$ & $11 / 28(46)$ & $6 / 19(31)$ & 0.3 \\
$\begin{array}{l}\text { Feeling of } \\
\text { incomplete }\end{array}$ & $15 / 28(43)$ & $3 / 19(16)$ & 0.1 \\
$\quad$ emptying & & $8 / 19(42)$ & 0.5 \\
Burning feeling & $9 / 28(32)$ & $3 / 19(16)$ & 0.3 \\
$\quad$ when & & & \\
$\quad$ urinating & & & \\
\hline
\end{tabular}

Note. pts. = number of patients.

authors' observations were subsequently supported by others. In a population cohort of 2109 middle-aged women, Fitzgerald et al. [15] reported a significant association between childhood LUTS and urinary tract infection and adult overactive bladder symptoms. Recently, Minassian et al. [17] found the highest prevalence of childhood dysfunctional voiding in women with urge UI, followed by mixed UI, and, finally, by stress UI (odds ratio $=1.4$, 95\% confidence interval $=0.8-2.5)$. Similarly, Levi d'Ancona et al. [18] reported that adult patients with urge $\mathrm{UI}$ and mixed $\mathrm{UI}$ were more likely to have history of enuresis in childhood than those with stress UI.

The results of the previously mentioned studies support the hypothesis of co-existing genetic and environmental factors during the developmental years in girls with $\mathrm{UI}$ and LUTS, which may predispose them to having similar symptoms in adulthood [17]. However, studies that evaluate girls with UI and LUTS from childhood into adulthood would be needed to confirm this hypothesis.

To our knowledge, data on the prevalence of LUTS in adulthood of girls treated for UI and LUTS in childhood have not been reported. Recently, the long-term outcome of UI and urge complaints in adult patients (average age: 27.8 years) who underwent intensive urotherapy in childhood has been re-assessed by Vijverberg et al. [20]. However, they did not investigate prevalence of LUTS in this population; they analyzed the outcome of intensive urotherapy, considering the persistence of one or more of the following variables: number of wet incidents during day, micturition frequency, urge complaints, and flow pattern. Therefore, our study is the first to investigate, in adulthood, those patients who suffered from UI and LUTS in childhood with the primary aim of determining the prevalence of UI and LUTS in adulthood.
In this study, the greater prevalence of LUTS in women who were treated in childhood for daytime UI/LUTS and NE than in control participants confirms the hypothesis that the presence of daytime UI, LUTS, and NE in childhood may have a negative impact on bladder function in adulthood. In particular, UI (34\% in patients vs. $7 \%$ in controls) and feeling of incomplete bladder emptying (49\% in patients and $28 \%$ in controls) were significantly prevalent $(p<0.0001)$ in women treated for LUTS in childhood than in controls.

Even if the prevalence of the remaining LUTS was higher in patients than in controls, no significant differences were found between the two groups. Symptoms as nicturia, urgency, bladder pain and straining to void were more highly represented in women treated for LUTS in childhood (42\%, $47 \%$, $32 \%, 29 \%$, respectively) than in controls $(29 \%, 35 \%$, $21 \%$, $21 \%$, respectively). On the contrary, symptoms difficult to define without previous explanation or recording in a diary, such as hesitancy, intermittency, abnormal voiding frequency, and burning feeling when urinating, were similarly reported by both patients $(40 \%, 47 \%, 68 \%, 25 \%$, respectively) and controls $(43 \%, 44 \%, 74 \%, 24 \%$, respectively).

It can be speculated that this result was biased by the select cohort of control participants consisting of nurses: better knowledge and greater sensitivity of nurses to such problems than the general population might explain the great representation of some LUTS in our control group. However, recent epidemiologic evidence seems to indicate an increasing prevalence of UI and LUTS in a healthy adult population. Irwin et al. [21] reported that $45.2 \%, 10.7 \%$, $8.2 \%$, and $21.5 \%$ of the worldwide population was affected, in 2008, by at least one LUTS, overactive bladder, UI, and LUTS/bladder outlet obstruction, respectively. Using an estimation model, the authors calculated that, in 2018, $18.4 \%, 20.1 \%, 21.6 \%$, and $18.5 \%$ of individuals will be affected by at least one LUTS, overactive bladder, UI, and LUTS/bladder outlet obstruction, respectively [21]. Therefore, the high prevalence of UI and LUTS in our control group might be an expression of this increasing prevalence of lower urinary tract disorders in the adult population. The relevant impact of UI and LUTS in the general adult population should be a stimulus for further research in order to prevent a these conditions and manage them early. In particular, a longitudinal study from childhood to adulthood could be useful to verify how behavioral modification and correct bladder training in a healthy pediatric population may invert the tendency to increase lower urinary tract disorders in children and adults.

Even if the average QoL score related to UI and LUTS did not differ significantly between patients and controls, the impact of UI and LUTS on QoL seems to be more relevant in women treated for LUTS in childhood than in controls: the number of patients who exhibit a QoL score $>5$ was significantly higher ( $p=0.0001)$ than those of controls.

In contrast to the previously mentioned studies in women who presented with UI and LUTS in adulthood [13-15], we did not find in our patients treated for UI, LUTS, and NE in childhood a significant prevalence of urgency in adulthood as a hallmark symptom of overactive bladder. On the contrary, suspected symptoms of a disorder of the emptying phase, such as a feeling of incomplete bladder emptying, was significantly represented in these 
patients. Therefore, a pathophysiological relationship between overactive bladder in adulthood and LUTS in childhood do not seem to be supported by our data. However, for a variety of reasons, such as difference in study populations, types and definitions of LUTS, and questionnaires administered, the comparison between results of the present study and those of the previously mentioned studies seems to be arduous.

In comparing the prevalence of UI and LUTS in adulthood between girls treated for daytime UI/LUTS (group A) and girls treated for NE (group B), no statistically significant differences were found. As the definition of NE in the period ranging between 1990 and 2000 did not include the distinction of monosymptomatic and non-monosymptomatic NE, the presence of associated daytime symptoms in some of the girls in this study with NE cannot be excluded. Moreover, our database did not include information on the different types of lower urinary tract dysfunction. For these limitations, definitive conclusions on the pathophysiologic relationships between LUTS in children and adults cannot be drawn.

UI and LUTS in adulthood were reported by most of our patients as occasional or occurring "sometimes". No patients required further evaluation to resolve symptoms. Although type and results of treatment of UI, LUTS, and NE in childhood were not found in our database, the modest severity of symptoms in adulthood seems to suggest a positive effect of pediatric treatment of UI and LUTS.

\section{Conclusions}

A greater prevalence of LUTS has been found in women who suffered from UI and LUTS in childhood than in a control population. These data support and reinforce the hypothesis of a link between lower urinary tract disorders in adulthood and UI and LUTS in childhood. UI and feeling of incomplete bladder emptying were more significantly prevalent in women with LUTS in childhood than in controls. In contrast to other studies, the prevalence of the remaining LUTS (especially urgency) was not significantly higher in patients than in controls. These findings seem to confirm a beneficial effect for young women in assessing and treating UI and LUTS in childhood. To what extent such a beneficial effect might be exerted will require a longitudinal follow-up study.

\section{Conflict of interest}

None.

\section{Acknowledgment}

Thanks to Professor Andrea Tubaro for making available the long form of the ICIQ- LUTS for this study.

\section{References}

[1] Bartoli S, Aguzzi G, Tarricone R. Impact on quality of life of urinary incontinence and overactive bladder: a systematic literature review. Urology 2010;75:491-500.
[2] Milsom I, Altman D, Lapitan MC, Nelson R, Sillen U, Thom D. Epidemiology of urinary (UI) and faecal (FI) incontinence and pelvic organ prolapse (POP). In: 4th international consultation on incontinence, July 5-8 2008, vol. 1. Health Publications Ltd; 2009. pp. 37-111.

[3] Neveus T, Sillen U. Lower urinary tract function in childhood; normal development and common functional disturbances. Acta Physiol 2013;207:85-92.

[4] Salvatore S, Serati M, Origoni M, Candiani M. Is overactive bladder in children and adults the same conditions?: ICI-RS 2011. Neurourol Urodyn 2012;31:349-51.

[5] Burton G, Wise BG, Cardozo LD, Cutner A, Kelleher CJ. Detrusor instability: is it inherited or just "passed on"? Neurourol and Urodyn 1992:11:458-62.

[6] Elia G, Bergman J, Dye TD. The familial incidence of urinary incontinence. Am J Obstet Gynecol 2002;187:53-5.

[7] Hannestad YS, Lie RT, Rortveit G, Hunskaar S. Familial risk of urinary incontinence in women: population based cross sectional study. BMJ 2004 Oct 16;329(7471):889-91.

[8] Rohr G, Kragstrup J, Gaist D, Christensen K. Genetic and environmental influences on urinary incontinence: a Danish population-based twin study of middle-aged and elderly women. Acta Obstet Gynecol Scand 2004 Oct;83(10):978-82.

[9] Wennberg AL, Altman D, Lundholm C, Klint A, Iliadou A, Peeker R, et al. Genetic influences are important for most but not all lower urinary tract symptoms: a population-based survey in a cohort of adult Swedish twins. Eur Urol 2011 Jun;59(6):1032-8.

[10] Von Gontard A, Heron J, Joinson C. Family history of nocturnal enuresis and urinary incontinence. Results for a large epidemiological study. J Urol 2011;185:2303-6.

[11] Eiberg H, Shaumburg HL, Von Gontard A, Rittig S. Linkage study of a large Danish 4-generation family with urge incontinence and nocturnal enuresis. J Urol 2001 Dec;166(6):2401-3.

[12] Cheung W, Bluth MJ, Johns C, Kahn S, Linn YY, Bluth MH. Peripheral blood mononuclear cell gene array profiles in patients with overactive bladder. Urology 2010;75:896-901.

[13] Bower WF, Yip SK, Yeung CK. Dysfunctional elimination symptoms in childhood and adulthood. J Urol 2005;174:1623-7.

[14] Bower WF, Sit FKY, Yeung CK. Nocturnal enuresis in adolescents and adults is associated with childhood elimination symptoms. J Urol 2006;176:1771-5.

[15] Fitzgerald MP, Thom DH, Wassel-Fyr C, Subak L, Brubaker L, Van Den Eeden SK, Brown JS. Reproductive Risks for Incontinence Study at Kaiser Research Group. Childhood urinary symptoms predict adult overactive bladder symptoms. J Urol 2006 Mar;175(3 Pt 1):989-93.

[16] Peters KM, Killinger KA, Ibrahim IA. Childhood symptoms and events in women with interstitial cystitis/painful bladder syndrome. Urology 2009;73:258-62.

[17] Minassian VA, Langroudi MH, Parek M, Poplawsky D, Kirchner HL, Sartorius J. Childhood dysfunctional voiding is differentially associated with urinary incontinence subtypes in women. World J Urol 2012;30:111-5.

[18] Levi D’Ancona CA, de Moraes Lopes MHB, Fileros-Martins AC, Lucio AC, Campos RM, Costa JV. Childhood enuresis is a risk factor for bladder dysfunction in adult life? Neurourol Urodyn 2012;31:634-6.

[19] Tubaro A, Zattoni F, Prezioso D, Scarpa RM, Pesce F, Rizzi CA, et al. Italian validation of the International Consultation on incontinence questionnaires. BJU Int 2006 Jan;97(1):101-8.

[20] Vijverberg MAW, Stortelder E, de Kort LMO, Kok TE, de Jong TPVM. Long-term follow-up of incontinence and urge complaints after intensive urotherapy in childhood (75 patients followed up for 16.2-21.8 years). Urology 2011;78:1391-6.

[21] Irwin DE, Kopp ZS, Agatep B, Milsom I, Abrams P. Worldwide prevalence estimates of lower urinary tract symptoms, overactive bladder, urinary incontinence and bladder outlet obstruction. BJU Int 2011;108:1132-8. 